\title{
HUKUMAN CAMBUK TERHADAP KONTROL SOSIAL
}

\author{
Indis Ferizal \\ Mahasiswaa Program Doktor \\ UIN Ar-Raniry Banda
}

\begin{abstract}
ABSTRAK
Hukuman cambuk yang diterapkan di Aceh merupakan salah satu kontrol sosial dan bentuk hukumannya diharapkan bisa memenuhi tendensi filosofis, yuridis dan sosiologis terhadap kesadaran hukum. Hukuman cambuk merupakan salah satu bentuk hukuman yang juga diharapkan dapat menumbuhkan sikap sadar hukum dan terciptanya masyarakat yang tertib hukum. Menurut Hukum Islam bahwa hukuman adalah demi kemaslahatan ummat dan mendidik pribadi si pelaku kejahatan.Pada dasarnya Tidak mudah dilakukannya upaya meningkatkan kesadaran hukum dan pengembangan budaya hukum pada masyarakat tanpa adanya dorongan dari individu masyarakat sendiri.Hal ini seharusnya menjadi perhatian khusus oleh pemerintah untuk lebih serius dalam melakukan sosialisasi sehingga kesadaran hukum dapat dipahami dan dilaksanakan oleh masyarakat dengan baik.

Kata Kunci : Hukuman Cambuk dan Kontrol Sosial.

Caning applied in Aceh is one of the social controls and the form of punishment is expected to fulfill the philosophical, juridical and sociological tendencies of legal awareness. Caning is one form of punishment that is also expected to foster a lawful attitude and the creation of an orderly society. According to Islamic law that punishment is for the benefit of the Ummah and educate the person of the perpetrator of the crime. Basically It is not easy to do efforts to increase legal awareness and the development of a legal culture in the community without encouragement from individual communities themselves. This should be of particular concern by the government to be more serious in conducting socialization so that legal awareness can be understood and implemented by the public properly.
\end{abstract}

Keywords: Caning and Social Control

\section{A. PENDAhULUAN}

Hukum Jinayat yang mulai diberlakukan pada tanggal 23
Oktober 2015 lalu merupakan upaya pelaksanaan syariat Islam di Aceh secara kaffah. Formulasi hukum 
jinayat yang diatur dalam Qanun Nomor 6 Tahun 2014 merupakan penyempurnaan dari beberapa ketentuan sebelumnya baik Qanun Nomor 12,13 dan 14 Tahun 2003. Asas yang dianut dalam pelaksanaan hukum jinayat mencakup a. keislaman; b. legalitas; c. keadilan dan keseimbangan; d. kemaslahatan; e. perlindungan hak asasi manusia; dan f. pembelajaran kepada masyarakat (tadabbur). Cakupan jenis jinayat yang diakomodir dalam qanun tersebut diantaranya: a. Khamar; b. Maisir; c. khalwat; d. Ikhtilath; e. Zina; f. Pelecehan seksual; g. Pemerkosaan; h. Qadzaf; i. Liwath; dan j. Musahaqah. Sepuluh jenis jinayat tersebut dibebankan hukuman 'Uqubat, ${ }^{\text {' }}$ Hudud, ${ }^{2}$ dan/atau Ta' $^{\prime}$ ir $^{3}$ bagi pelaku

1 Uqubath adalah hukuman yang dapat dijatuhkan oleh hakim terhadap pelaku Jarimah, lihat Pasal 1 angka 17 Qanun No. 6 Tahun 2014 tentang Hukum Jinayat

${ }^{2} \mathrm{Hudud}$ adalah jenis 'Uqubat yang bentuk dan besarannya telah ditentukan di dalam Qanun secara tegas, lihat Pasal 1 angka 18 Qanun No. 6 Tahun 2014 tentang Qanun Jinayah

${ }^{3} \mathrm{Ta}$ 'zir adalah jenis 'Uqubat yang telah ditentukan dalam Qanun yang bentuknya bersifat pilihan dan besarannya sebagaimana diatur dalam Bagian Kedua Pasal 4 Qanun No. 6 Tahun 2014. Uqubat adalah hukuman yang dapat dijatuhkan oleh hakim terhadap pelaku Jarimah. Hudud adalah jenis 'Uqubat yang bentuk dan besarannya telah ditentukan di dalam qanun secara tegas. Ta'zir adalah jenis 'Uqubat yang telah ditentukan dalam qanun yang bentuknya bersifat pilihan dan besarannya dalam batas tertinggi dan/atau terendah. ${ }^{4}$ Pelaksanaan syariat Islam di Aceh merupakan keinginan masyarakat Aceh sendiri dalam mewujudkan keamanan dan ketenteraman serta kesejahteraan dalam kehidupan. Sebagaimana firman Allah SWT dalam Quran Surah Al - Maidah 49: Artinys: "Dan hendaklah kamu memutuskan perkara di antara mereka menurut apa yang diturunkan Allah, dan janganlah kamu mengikuti hawa nafsu mereka. dan berhati-

dalam batas tertinggi dan/atau terendah., lihat Pasal 1 angka 19 Qanun No. 6 Tahun 2014 tentang Hukum Jinayat

${ }^{4}$ Lihat Pasal 1 angka 17 sampai dengan 19 Qanun Aceh No. 6 Tahun 2014 tentang Hukum Jinayat 
hatilah kamu terhadap mereka, supaya mereka tidak memalingkan kaтu dari sebahagian apa yang Telah diturunkan Allah kepadamu... (Q.s Al-maidah: 49).

Hukuman cambuk diperkenalkan Alquran untuk dua delik yaitu zina (an-Nur: 2) dan menuduh berzina (an-Nur: 4). Dalam an-Nur: 2 dikemukakan bahwa pelaku zina dikenai sanksi 100 kali cambuk, sedangkan dalam an-Nur: 4 disebutkan bahwa orang-orang yang menuduh orang lain berzina diancam dengan hukuman cambuk 100 kali. Selain menguatkan ketentuan sanksi untuk dua delik tersebut, hadis menambahkan satu jenis delik lain yang dihukum cambuk yaitu minum khamar yang diancam 40 kali cambuk.

Sebagaimana disebutkan dalam Alquran Surat An-Nur ayat 2 dan 4 menyebutkan bahwa: Artinya: "Perempuan yang berzina dan lakilaki yang berzina, Maka deralah tiaptiap seorang dari keduanya seratus dali dera, dan janganlah belas kasihan kepada keduanya mencegah kamu untuk (menjalankan) agama Allah, jika kamu beriman kepada Allah, dan hari akhirat, dan hendaklah (pelaksanaan) hukuman mereka disaksikan oleh sekumpulan orang-orang yang beriman”.

Selanjutnya dalam ayat 4 disebutkan juga bahwa: Artinya: "Dan orang-orang yang menuduh wanita-wanita yang baik-baik (berbuat zina) dan mereka tidak mendatangkan empat orang saksi, Maka deralah mereka (yang menuduh itu) delapan puluh kali dera, dan janganlah kamu terima kesaksian mereka buat selamalamanya. dan mereka Itulah orangorang yang fasik.

Dalam hukum pidana Islam, delik zina, menuduh zina $(k a d z b)$, dan khamar dikategorikan para ulama kepada kejahatan hudud (al-jaraim al-hudud) bersama pencurian (sirqah), perampokan (hirabah), murtad (riddah), dan pemberontakan

\footnotetext{
${ }^{5}$ Yang dimaksud wanita-wanita yang baik disini adalah wanita-wanita yang Suci, akil balig dan muslimah.
} 
(al-baghy). Hudud adalah tindak pidana yang dihukum dengan had, sedangkan had sendiri adalah hukuman tertentu yang sudah ditentukan atau menjadi hak Allah. Dikatakan hak Allah karena tidak ada kemungkinan dapat dibatalkan oleh seseorang atau sekelompok orang. ${ }^{6}$

Ayat tentang tata laksana cambuk di atas berbicara dalam konteks zina semata, bukan dalam kasus lain. Karena penyamaan demikian, muncul satu kesimpulan bahwa tata laksana hukuman cambuk dalam Islam condong merupakan kebijakan penguasa (khalifah). Aspek syariat dalam pelaksanaan hukuman cambuk itu terletak pada tujuannya (maqashid), yaitu agar orang lain tahu dan megambil pelajaran dari kasus tersebut. ${ }^{7}$

Untuk efektivitas pelaksanaan qanun ini di samping adanya lembaga penyidikan dan penuntutan, juga

${ }^{6}$ Abdul Qadir Audah, Al-Tasyri alJina'i al-Islamy: Muqarinan bi al-Qanun alWadh $i$, cet. 13 (Beirut: Mu'assasat alRisalat, 1994), hlm. 79-80.

${ }^{7}$ Abdul Qadir Audah, Al-Tasyri alJina'i al-Islamy..., hlm. 79-80. dilakukan pengawasan yang meliputi upaya pembinaan si pelaku jarimah minuman khamar, maisir dan khalwat oleh pejabat Wilayatu al-Hisbah. Di samping itu juga kepada masyarakat diberikan peranan untuk mencegah terjadinya jarimah minuman khamar, maisir dan khalwat dalam rangka memenuhi kewajiban sebagai seorang muslim untuk melakukan amar ma'ruf nahi mungkar. ${ }^{8}$

\section{B. NORMA HUKUM DALAM MASYARAKAT}

Nilai sosial adalah sekelompok ukuran, patokanpatokan, keyakinan, atau anggapan yang hidup dan berkembang di dalam kehidupan masyarakat tertentu. sekelompok keyakinan-keyakinan tersebut dianut oleh banyak orang di dalam komunitasnya, dan memuat mengenai apa yang beanr, apa yang salah, dan apa yang pantas untuk dilakukan serta yang tidak pantas

${ }^{8}$ Rasyid Rizani, kedudukan qanun jinayat propinsi nanggroe Aceh darussalam dalam sistem hukum nasional, https://dokumen.tips/download/link/qanunjinayat-dlm-sistem-hukum-nasional, diakses pada tanggal 11 April 2018 
untuk dilakukan di dalam kehidupan sehari-hari. Berbicara mengenai aspek nilai dalam masyarakat juga menelusuri tentang moral. Moral adalah keharusan perilaku yang dibawakan oleh nilai. Sedangkan Norma merupakan Sumber dasar hukum yang menguatkan kedudukan konsep, nilai, moral serta perilaku yang dilakukan. ${ }^{9}$

Ruang lingkup norma agama, sosial dan hukum:

a. Norma sosial adalah kebiasaan umum yang menjadi patokan perilaku dalam suatu kelompok masyarakat dan batasan wilayah tertentu. Norma akan berkembang seiring dengan kesepakatan-kesepakatan sosial masyarakatnya, sering juga disebut dengan peraturan sosial. Norma menyangkut perilakuperilaku yang pantas dilakukan dalam menjalani interaksi sosialnya.

${ }^{9}$ Jimly Asshiddiqie dan M. Ali Safaat. Teori Hans Kelsen Tentang Hukum, (Jakarta: Sekretariat Jenderal dan Kepaniteraan Mahkamah Konstitusi RI, 2006), hlm. 11 b. Norma agama adalah petunjuk hidup yang berasal dari Tuhan yang disampaikan melalui utusan-Nya yang berisi perintah, larangan dan anjurananjuran. Pelanggar norma agama mendapatkan sanksi secara tidak langsung, artinya pelanggarnya baru akan menerima sanksinya nanti di akhirat berupa siksaan di neraka.

c. Norma hukum adalah aturan sosial yang dibuat oleh lembaga-lembaga tertentu, misalnya pemerintah, sehingga dengan tegas dapat melarang serta memaksa orang untuk dapat berperilaku sesuai dengan keinginan pembuat peraturan itu sendiri. Pelanggaran terhadap norma ini berupa sanksi denda sampai hukuman fisik (dipenjara, hukuman mati). ${ }^{10}$

Secara umum, norma hukum diartikan sebagai aturan sosial yang

${ }^{10}$ Jimly Asshiddiqie dan M. Ali Safaat. Teori Hans Kelsen..., hlm. 11. 
dibuat oleh lembaga tertentu seperti lembaga resmi milik pemerintahan, sehingga bisa memaksa masyarakat untuk berperilaku sesuai dengan isi aturan tersebut. ${ }^{11}$ Orang yang melanggar norma ini akan dikenakan sanksi tegas. Bisa berupa denda ataupun hukuman fisik seperti dipenjara atau hukuman mati.

Adapun pengertian lain tentang norma hukum adalah sebagai berikut:

a) Norma hukum merupakan aturan yang sengaja dibuat negara sebagai alat perlengkapan negara, dan berlakunya aturan ini dapat dipaksa oleh petugas yang berwenang seperti polisi, jaksa, hakim, dan lain sebagainya.

b) Norma hukum merupakan aturan hidup yang diciptakan oleh negara atau lembaga negara yang berwenang.

c) Norma hukum merupakan jenis norma yang sifatnya mengikat

\footnotetext{
${ }^{11}$ Soerjono Soekanto dan Purnadi Purbacaraka. Sendi-Sendi Ilmu Hukum dan Tata Hukum. (Bandung: Citra Aditya Bakti, 1993), hlm. 33
}

dan memaksa. Mengikat artinya norma ini berlaku pada setiap orang tanpa terkecuali. Sedangkan memaksa artinya semua peraturan yang berlaku harus ditaati oleh siapapun. ${ }^{12}$

Mahfud MD dalam bukunya menyebutkan bahwa syarat keberlakuan hukum tidak hanya berupa bahwa hukum tersebut telah ditetapkan, tetapi hukum tersebut juga bisa berlaku secara efektif. Suatu produk hukum yang baik dan benar adalah yang sah dan berlaku efektif. Syarat-syarat ini juga merupakan titik pangkal dalam mengidentifikasi kesalahan-kesalahan dalam produk hukum, khususnya beberapa aturan daerah. Syarat-syarat keberlakuan tersebut adalah:

1) Memenuhi syarat Filosofi: Norma hukum berlaku efektif jika memenuhi cita-cita kolektif masyarakatnya.

2) Memenuhi syarat yuridis: Secara yuridis, ada 3 kreteria

${ }^{12}$ Jimly Asshiddiqie dan M. Ali Safaat. Teori Hans Kelsen..., hlm. 20. 
suatu norma bisa berlaku

efektif, yaitu:

- Norma tersebut tidak bertentangan dan sesuai dengan norma yang lebih tinggi (materiil toetsing). Bertentangan (contra legem), Tidak sesuai (penyimpangan, misalnya penambahan sesuatu yang pada norma di atasnya sudah ditegaskan).

- Norma yang berlaku ditetapkan dengan prosedur yang sah (formil toetsing)

- Norma yang berlaku ditetapkan oleh lembaga yang berwenang (formil toetsing)

3) Memenuhi syarat Sosiologis: Syarat sosiologis diperlukan untuk memperoleh social support. Ada berbagai macam teori tentang berlakunya hukum secara sosiologis, diantaranya yaitu: a) Harus diterima oleh masyarakat (Teori Social Acceptance)

b) Diakui oleh masyarakat (teori social recognition)

c) Diberlakukan dengan kekuasaan (Power Theory)

d) Kenyataannya berlaku (teori faktisitas)

4) Memenuhi Syarat Politis: Berlakunya hukum harus mendapatkan dukungan politis. Hukum merupakan produk dari konfigurasi politik. ${ }^{13}$

Qanun Jinayat telah mencerminkan keberlakuan secara yuridis karena pembentukannya didasarkan pada norma yang lebih tinggi tingkatannya dan terbentuk menurut cara yang ditetapkan sesuai wewenang propinsi Aceh sebagai daerah pelaksana otonomi khusus. Adapun secara sosiologis, dikarenakan masyarakat di Aceh memang telah menerima syariah Islam sejak dahulu dan kondisi masyarakat Aceh yang homogen

${ }^{13}$ Mahfud MD, Politik Hukum di Indonesia, (Jakarta: LP3ES, 1998), hlm. 44 
tentu saja lebih mendukung pelaksanaan Peraturan Daerah syariah Islam. Selain itu penerapan syariah Islam di Aceh terkait erat dengan political expediency Pemerintah Pusat guna mempertahankan Aceh dalam Negara Kesatuan Republik Indonesia (NKRI). Secara filosofis, uqubat yang terdapat dalam Qanun Jinayat tersebut sesuai dengan maqasid syariah yaitu menjaga agama, jiwa, akal, keturunan dan harta.

Qanun-qanun jinayat tersebut dibentuk sebagai upaya preventif agar pelaksanaan syariat Islam di Aceh dapat dilaksanakan secara efektif dan efisien. Efektif dalam arti hukumannya tidak memerlukan adanya penjara yang tentunya memerlukan biaya, baik biaya konsumtif maupun biaya-biaya lainnya yang timbul karena perbuatan jinayat tersebut. Efisien artinya, hukuman yang diberikan dapat langsung sock terapi kepada pelaku jinayat, karena dicambuk di hadapan khalayak ramai.
C. SYARIAT ISLAM DALAM KEHIDUPAN MASYARAKAT

Sifat fanatisme terhadap syariat Islam yang telah mengakar kuat dalam masyarakat Aceh menjadikan pelaksanaan syariat Islam dinilai mudah dilaksanakan. Menyimak dari masa sejarah, pelaksanaan hukum Islam telah dipraktekkan pada masa kesultanan yang ada di nusantara. Rifyal Ka'bah menyebutkan bahwa sebelum kedatangan penjajah Belanda, hukum Islam telah menjadi hukum positif di kerajaan Islam. Atas dasar tersebut tentunya kedudukan hukum Islam sebagai hukum positif pertama di nusantara dan para penguasa memposisikan hukum Islam sebagai hukum negara. ${ }^{14}$

Perkembangan hukum Islam di Aceh tidak dapat dilepaskan dari peran sultan yang memerintah dan memegang kekuasan pada masa itu. Peran sultan yang absolut dan otoriter menyebabkan agama rakyat adalah

\footnotetext{
${ }^{14}$ Rifyal Ka'bah, Hukum Islam di Indonesia, (Jakarta: Universitas Yasri, 1999), hlm. 26
} 
agama sultan mereka. Para raja Aceh yang sejak berdirinya kerajaan sudah menjadi pemeluk Islam, membuat Islam menjadi agama yang dianut oleh masyarakat Aceh. Di Kerajaan Aceh Darussalam, peran keagamaan dipimpin oleh seorang ulama yang disebut syaikhul Islam. ${ }^{15}$

Kekuasaan yang tidak terbatas yang dimiliki sultan dalam melaksanakan hukum Islam menyebabkan hukum Islam yang ada di Aceh berubah menjadi adat. Sebagai adat, ia terkadang melangkah jauh melebihi hukum Islam itu sendiri bahkan cenderung menjadi "hukum sultan”. Dalam konteks ini, sultan seolah memiliki hak yang tidak terbatas dalam melaksanakan hukum kepada orang yang bersalah, terutama orang yang tidak taat kepada sultan. Dalam Bustan al-Salatin, Nuruddin ar-Raniry mengatakan: “...segala yang berbuat khianat akan segala raja-raja tak dapat tiada datang jua ke atas mereka itu murka Allah Ta'ala fadhihat, hubayahubaya hal

\footnotetext{
${ }^{15}$ Sehat Ihsan Shadiqin, Islam dalam Masyarakat Kosmopolit ... Op., Cit., hlm. 27
}

segala hamba Allah, jangan kamu berbuat khianat akan segala rajaraja, tak dapat tiada pekerjaan yang demikian itu dinyatakan Allah Ta'ala juga kepadanya."16.

Adapun secara sosiologis, dikarenakan masyarakat di Aceh memang telah menerima syariah Islam sejak dahulu dan kondisi masyarakat Aceh yang homogen tentu saja lebih mendukung pelaksanaan Peraturan Daerah syariah Islam. Selain itu penerapan syariah Islam di Aceh terkait erat dengan political expediency Pemerintah Pusat guna mempertahankan Aceh dalam Negara Kesatuan Republik Indonesia (NKRI). Secara filosofis, uqubat yang terdapat dalam Qanun Jinayat tersebut sesuai dengan maqasid syariah yaitu menjaga agama, jiwa, akal, keturunan dan harta. Prospek qanun jinayat ini ke depannya akan bertahan dan berkembang karena sesuai dengan nilai-nilai luhur bangsa Indonesia yang tertuang dalam

\footnotetext{
${ }^{16}$ Nuruddin ar-Raniry, Bustan alSalatin, Bab II, Pasal 13, diedit oleh T. Iskandar, (Kuala Lumpur: Dewan Bahasa dan Pusataka, 1966), hlm. 46.
} 
Pancasila dan UUD 1945 serta undang-undang lainnya, juga didukung dengan hukum yang hidup dalam masyarakat Aceh.

\section{HUKUMAN}

TERHADAP

SOSIAL

Persepsi masyarakat terhadap pelaksanaan hukum cambuk di Aceh lebih banyak ditentukan oleh pemahaman dan pengetahuan seseorang atau kelompok (masyarakat) melalui serentatan tahapan pemikiran yang berkembang dalam masyarakat yang dipengaruhi oleh latar belakang sosial dan budaya yang membentuk konsep diri melalui proses sosialisasi nilai dan normanorma yang berkembang dalam masyarakat bersangkutan sehingga pemahaman dari ajaran agama yang menjadi latar belakang sosial masyarakat Aceh dan budaya yang dihayati masyarakat memberi pengaruh terhadap persepsi seseorang. Selain itu pelaksanaan hukum cambuk berdampak positif bagi masyarakat karena hukum cambuk bukan saja membuat efek jera melainkan lebih memberikan nilai-nilai edukasi, moral, dan Kontrol sosial dalam tatanan kehidupan masyarakat. ${ }^{17}$

Terkait strategi yang dilakukan oleh pemerintah daerah baik tingkat provinsi maupun kabupaten/kota dalam pelaksanaan qanun jinayah terkait pelaksanaan hukuman cambuk telah banyak dilakukan guna peningkatan kesadaran hukum dalam hal aktualisasi syariat Islam secara kaffah. Hukuman cambuk juga mempunyai fungsi sebagai kontrol sosial dalam masyarakat, dalam mencegah terjadinya jarimah yang dilakukan oleh masyarakat.

Menurut Kamus Besar Bahasa Indonesia menyebutkan bahwa pengertian dari pemahaman adalah proses, cara, perbuatan

\footnotetext{
${ }^{17}$ Rizky Rullya Ananda, Persepsi Masyarakat Terhadap Pelaksanaan Hukum Cambuk Di Kota Banda Aceh, (Skripsi, Fakultas Hukum Universitas Syiah Kuala, 2016), hlm. i
} 
memahami atau memahamkan. ${ }^{18}$. Pemahaman hukum diartikan sebagai sejumlah informasi yang dimiliki seseorang mengenai isi peraturan dari suatu hukum tertentu. Dengan kata lain, pemahaman hukum adalah suatu pengertian terhadap isi dan tujuan suatu peraturan dalam hukum tertentu serta manfaatnya bagi pihak-pihak yang kehidupannya diatur oleh peraturan tersebut. ${ }^{19}$

$$
\text { Soejono }
$$

Sokamto memberikan pengertian Kesadaran Hukum adalah suatu percobaan penerapan metode yuridis empiris untuk mngukur kepatuhan hukum dalam menaati peraturan. Sebenarnya merupakan kesadaran akan nilai-nilai yang terdapat di dalam diri manusia, tentang hukum yang ada atau tentang hukum yang diharapkan ada, sebetulnya yang ditekankan adalah nilai-nilai tentang fungsi hukum dan bukan suatu penilaian terhadap hukum. ${ }^{20}$

\footnotetext{
${ }^{18}$ Rahmat Hakim Loc., Cit.

${ }^{19}$ Otje Salman, Kesadaran Hukum Masyarakat Terhadap Hukum Waris, (Bandung: Alumni,1993), hlm. 41.

${ }^{20}$ Otje Salman, Kesadaran..., hlm. 41.
}

Istilah sadar berarti mengetahui atau mengerti tentang tindak hukum yang dilakukan dan akibat hukumnya, serta dapat membedakan baik buruk. Merasa dan mengerti bahwa perilaku tertentu diatur oleh hukum disebut kesadaran hukum. ${ }^{21}$. Kesadaran dapat diartikan pula sebagai sikap atau perilaku mengetahui atau mengerti dan taat pada adat istiadat serta kebiasaan hidup dalam masyarakat. ${ }^{22}$

Pada umumnya kesadaran hukum juga dikaitkan dengan ketaatan hukum atau efektivitas hukum. Dengan kata lain kesadaran hukum menyangkut masalah apakah ketentuan dan tujuan hukuman cambuk benar-benar berfungsi atau tidak dalam masyarakat. Lebih lanjut menurut Atang Hermawan dalam tulisannya menyebutkan bahwa

${ }^{21}$ Miftahur Rifqi, Tingkat Kesadaran Hukum Mahasiswa Terhadap Qanun No. 6 Tahun 2014 Tentang Hukum Jinayat (Studi Kasus Mahasiswa Fakultas Syariah \& Hukum UIN Ar-Raniry), (Jurnal LEGITIMASI, Vol. VI No. 1, Januari-Juni 2017), hlm. 67

${ }^{22}$ AW. Widjaja, Kesadaran Hukum Manusia dan Masyarakat Pancasila, (Jakarta: CV.Era Swasta, 1982), hlm. 16. 
tingkat kesadaran hukum masyarakat maupun pemerintah sendiri masih sangat rendah dan dapat menjadi sebab belum tegaknya prinsip-prinsip negara hukum di Indonesia. Sebabsebabnya antara lain:

1. Kurang mengetahui adanya ketentuan hukum dan kurang memahami hukum itu sendiri;

2. Cenderung kurang menghargai dan mempercayai proses penegakan hukum yang sedang berlangsung;

3. Faktor integritas dan moral yang rendah;

4. Faktor sarana dan prasarana yang belum memadai. ${ }^{23}$

Soekanto dalam Nurhidayat menyebutkan bahwa indikator kesadaran hukum mencakup beberapa hal yaitu :

a) Pengetahuan hukum. yang dimaksud dengan pengetahuan hukum adalah seseorang telah mengetahui bahwa perilakuperilaku tertentu telah diatur oleh hukum.

\footnotetext{
${ }^{23}$ AW. Widjaja, Kesadaran Hukum Manusia.., hlm. 52
}

b) Pemahaman hukum Pengetahuan dan pemahaman seseorang mengenai aturanaturan tertentu, misalnya adanya pengetahuan dan pemahaman yang benar tentang hakikat dan arti pentingnya peraturan atau aturan hukum. ${ }^{24}$

Agar terjadi suatu keserasian yang profesional antara hukum yang diterapkan dengan kesadaran hukum dari masyarakat umum, maka peraturan itu sendiri harus rasional dan dilaksanakan dengan prosedur yang teratur dan wajar. Sosiologi hukum sangat berperan dalam upaya sosialisasi hukum demi untuk meningkatkan kesadaran hukum yang positif, bagi warga masyarakat secara keseluruhan, maupun dari kalangan penegak hukum. ${ }^{25}$

${ }^{24}$ Nurhidayat, Al aziz, Kesadaran Hukum Warga Masyarakat Desa Lemahjaya Kecamatan Wanadadi Kabupaten Banjarnegara Terhadap Pelaksanaan Undang-undang No. 1 Tahun 1974 Tentang Perkawinan, (Tesis, UNNES, Semarang : 2006), hlm. 41

${ }^{25}$ Soerjono Soekanto, Pokok-Pokok Sosiologi Hukum, (Jakarta: Rajawali Pers, 2012), hlm. 13 
Al-Qur'an juga telah mengatur tentang makna dari suatu yang penting bagi manusia, begitu juga halnya dengan kesadaran diri manusia terhadap hukum, agar manusia patuh menjalankan hukum itu sendiri. Pentingnya kesadaran ini terkandung dalam Al-Quran Surat AlHasyr ayat 19: Artinya: "Dan janganlah kamu seperti orang-orang yang lupa kepada Allah, lalu Allah menjadikan mereka lupa kepada mereka sendiri. mereka Itulah orangorang yang fasik"(Q.S Al Hasyr: 19) Dalam ayat di atas, dikatakan bahwa melupakan Allah menyebabkan kita melupakan diri kita sendiri, dan pada akhirnya membawa kita pada pelanggaran. Arti kata melanggar disini dimaknai dengan melanggar norma-norma agama, adat dan hukum yang berlaku. Ide tentang kesadaran masyarakat sebagai dasar sahnya hukum positif yang dibuat tertulis juga ditemukan dalam ajaran tentang rechtsgefuhl atau rechtsbewustzinjn kesadaran. kesadaran diri merupakan

yang intinya adalah bahwa tidak ada hukum yang mengikat warga masyarakat kecuali atas dasar kesadaran hukumnya. Hal tersebut merupakan salah satu aspek lainnya dari kesadaran hukum yang seringkali dikaitkan dengan pembentukan hukum dan efektivitas hukum. ${ }^{26}$

\section{E. PENUTUP}

Hukuman cambuk adalah pesan moral kepada kita semua untuk saling menjaga diri dari perbuatan yang dilarang oleh agama."Cambuk itu memang harus terbuka agar pesan morilnya sampai kepada masyarakat lain, dan ini bukan semata-mata sebagai bentuk hukuman yang berujung pada efek jera, namun lebih kepada pembinaan atau kontrol sosial.

Tidak mudah dilakukannya upaya meningkatkan kesadaran hukum dan pengembangan budaya hukum pada masyarakat tanpa adanya

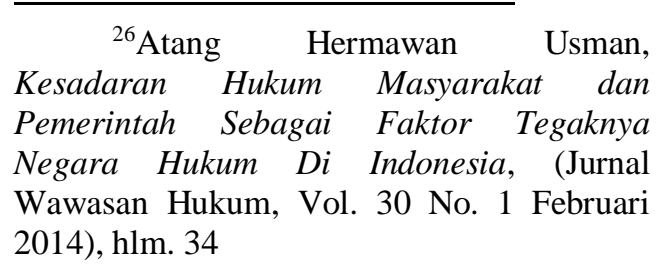


dorongan dari individu masyarakat sendiri. Aspek kendala yang dihadapi salah satunya adalah rendahnya tingkat pendidikan masyarakat secara mayoritas di Aceh. Disamping itu, terdapat kelemahan dari beberapa program metode peningkatan kesadaran hukum yang dapat langsung dipahami oleh masyarakat dengan tingkatan pendidikan yang bervariasi. Tentunya dipahami sebagai tantangan ke depan yang perlu ditindaklanjuti dalam rangka meningkatkan kesadaran hukum masyarakat Aceh terhadap materi hukum Islam yang perlu dipandang tidak hanya melalui pendidikan hukum tetapi juga melalui berbagai disiplin ilmu.

\section{DAFTAR PUSTAKA}

Abdul Qadir Audah, Al-Tasyri al-Jina'i al-Islamy: Muqarinan bi al-Qanun alWadh $i$, cet. 13 Mu'eassasat al-Risalat, Beirut, 1994.

Atang Hermawan Usman, Kesadaran Hukum Masyarakat dan Pemerintah Sebagai Faktor Tegaknya Negara Hukum Di Indonesia, Jurnal Wawasan Hukum, Vol. 30 No. 1 Februari 2014.

AW. Widjaja, Kesadaran Hukum Manusia dan Masyarakat Pancasila, CV.Era Swasta, Jakarta, 1982.

Jimly Asshiddiqie dan M. Ali Safaat. Teori Hans Kelsen Tentang Hukum,

Sekretariat Jenderal dan Kepaniteraan Mahkamah Konstitusi RI: Jakarta, 2006.

Mahfud MD, Politik Hukum di Indonesia, LP3ES, Jakarta, 1998.

Miftahur Rifqi, Tingkat Kesadaran Hukum Mahasiswa Terhadap Qanun No. 6 Tahun 2014 Tentang Hukum Jinayat (Studi Kasus Mahasiswa Fakultas Syariah \& Hukum UIN Ar-Raniry), Jurnal legitimasi,. VI No. 1, Januari-Juni 2017. 
Munawar Djalil, Kepala Dinas Syariat Islam Provinsi Aceh, wawancara, pada tanggal 17 Januari 2018.

Nurhidayat, Al aziz, Kesadaran Hukum Warga Masyarakat Desa Lemahjaya Kecamatan Wanadadi Kabupaten Banjarnegara Terhadap Pelaksanaan Undang-undang No. 1 Tahun 1974 Tentang Perkawinan, Tesis, UNNES, Semarang : 2006.

Otje Salman, Kesadaran Hukum Masyarakat Terhadap Hukum Waris, Alumni, Bandung, 1993.

Rasyid Rizani, kedudukan qanun jinayat propinsi nanggroe Aceh darussalam dalam histem hukum nasional, https://dokumen.tips/download/link/qanun-jinayat-dlm-sistem-hukumnasional, diakses pada tanggal 11 April 2018

Rifyal Ka'bah, Hukum Islam di Indonesia, Universitas Yasri, Jakarta, 1999.

Rizky Rullya Ananda, Persepsi Masyarakat Terhadap Pelaksanaan Hukum Cambuk Di Kota Banda Aceh, Skripsi, Fakultas Hukum Universitas Syiah Kuala, 2016.

Soerjono Soekanto dan Purnadi Purbacaraka. Sendi-Sendi Ilmu Hukum dan Tata Hukum. Citra Aditya Bakti: Bandung, 1993. , Pokok-Pokok Sosiologi Hukum, Rajawali Pers, Jakarta, 2012. 